\title{
RESTART: What, Why, How and So What?
}

\subsection{Responsibility and Opportunity}

In 2014, the technology company Dell entered into an agreement with the supplier Newlight Technologies_an innovative plastics manufacturer from California. The thing to note about Dell's new supplier was that the plastic it delivered to Dell was certified carbon-negative.

In order to produce the plastic, Newlight captures $\mathrm{CO}_{2}$ from the chimneys of other companies and uses it as the most important input in its plastic production. In other words, the more plastic Newlight produces, the larger the reduction of $\mathrm{CO}_{2}$ in the atmosphere. In addition, the plastic produced by Newlight is biodegradable. Newlight can deliver this product because it has developed technology that makes it possible to capture greenhouse gases in the air and turn them into biodegradable plastic.

Newlight plastic is competitive in quality and price, and it is used for everything from plastic chairs to the bags in which Dell packages its laptops. This implies that Newlight not only contributes to solve the climate problem, it has also established a business model that could potentially provide it with clients both upstream and downstream in its value chain. 
Upstream, it could be paid by companies that have a surplus of $\mathrm{CO}_{2}$ and a need to get rid of it. Downstream, it is already paid by customers of its plastic. In this way, the company could eventually get a double revenue model. Dell, like many other comparable companies, wants greener products as part of an attempt to reduce the environmental footprint of its value chain. Therefore, Newlight already has a long list of clients on the Fortune 500 list aiming to reduce the negative impact of their plastic use. And in 2016, Newlight entered into a comprehensive partnership with IKEA, through which Newlight will supply IKEA with carbon-negative plastic for use in its products.

Some 20 years earlier, in 1994, Ray Anderson, the founder and CEO of Interface, was asked to comment on the company's environmental vision at an internal work meeting. Interface was a large player in the international carpet market, and the reason for the meeting was that the company's customers and collaborative partners had begun to question how its carpets were manufactured and what influence Interface had on society and the environment (Anderson 2002). Ray drew inspiration for his speech from reading Paul Hawken's The Ecology of Commerce (Hawken 1993). It suddenly occurred to him that the company he had been running for 21 years not only lacked an environmental vision but rather the company was an environmental culprit. This was a revelation to Anderson, and it led to his vision of reducing Interface's ecological footprint to zero by 2020 ("Mission Zero"). This required an entirely new way of thinking and a completely new business model to turn the company around from being an environmental villain to becoming a leader in sustainability (Anderson 2010).

To achieve this ambitious objective, the company needed to develop new products and had to turn its processes upside down to find new ways of designing, manufacturing and distributing its carpets. In addition, it aimed to find alternative sources of energy. Perhaps most fundamentally, Interface changed its business model from one based on selling carpets to end users to a business model based on a so-called product-service system. This implied that it leased carpets to its customers, in a way that the company had the responsibility for maintenance, cleaning and so on. When carpet tiles were destroyed or worn down, Interface replaced them and collected the old tiles for reuse in the production of new carpets. In 
this way, Interface could sell more services to its customers, while at the same time driving down the cost of input factors for its carpets (see, e.g., Botsman and Rogers 2010; Jørgensen and Pedersen 2017). Interface is still working toward these goals today-even after Anderson's deathand the company has made good progress toward realizing its environmental vision, while at the same time remaining a market leader in its industrial segment.

These two companies, Newlight and Interface, both actively address the environmental and social issues facing the world, and they have developed business models that strive to be both sustainable and profitable. While Ray Anderson experienced an epiphany that led him to take responsibility for the sustainability issues of his company, we can say that Newlight has based its business model on the opportunity the sustainability issue provides for businesses to find profitable solutions to these pressing problems. This book revolves around both of these approaches: responsibilities and opportunities for creating more sustainable economies. Most importantly, however, it addresses how these companies aim to align sustainability and profitability.

\section{Companies are Problem Solvers}

Increasing attention is being paid to sustainability issues in companies across all industries (e.g., Kiron et al. 2012). This is not only because the severity of the problem has begun to dawn on our societies, but also because companies are realizing that in order to remain profitable over time, they will have to take sustainability into account and, ideally, deal with the problems we face (e.g., Eccles et al. 2015; Khan et al. 2016). This may involve changing their business models to adapt to the sustainability issue or it could involve designing business models that actively contribute to solving the problem (e.g., Wells 2013; Boons and LüdekeFreund 2013). Therefore, insurance companies are working to ensure that customers can adapt to the new climate reality, fish farming companies are changing their production methods to become more sustainable and an increasing part of assets under management in financial markets 
take the so-called ESG (environmental, social, governance) factors into account.

On the one hand, the sustainability issue is important to business because it affects the conditions for economic activities (Pachauri and Meyer 2014; Rockström et al. 2009). When resources become scarcer because of overuse or climate change, the costs and risks associated with resources increase and the rewards of adapting increase (e.g., Evans 2011; Krautkraemer 1998). When markets become unstable due to geopolitical and environmental risks, the stability of the economy is also disturbed (e.g., Fitzpatrick 1983; Miller 1992; Søreide 2016). And not least: when customers, employees, investors and other stakeholders place greater demands on social and environmental performance, openness and transparency, and expect that products and services are made more sustainable, it becomes less attractive to be the company that cannot live up to those expectations (e.g., Sen et al. 2016; Skarmeas and Leonidou 2013). Perhaps this is why companies such as Equinor and Shell choose to pull out of oil sands mining, and food producers like Orkla stop using palm oil as an input factor? More and more research shows that sustainability and profitability are possible to align and that improving sustainability performance can even lead to certain types of competitive advantage that are unavailable to businesses that are not sustainable (Eccles et al. 2015, 2016; Khan et al. 2016; Kiron et al., 2012; Jørgensen and Pedersen 2015). This means that the incentives to become greener become stronger.

On the other hand, the sustainability issue is important to business simply because companies are part of the problem. Companies have played a major role in the development of our sustainability problems, and it is difficult to imagine that these problems can be solved without their efforts. To achieve this, there is a need for both companies that take responsibility for reducing their negative influence on society and the environment and companies that manage to find profitable ways to exploit the business opportunities that arise because of those problems. Fortunately, we see that both things are happening-although perhaps not quickly enough. 


\section{Responsibility and Opportunity: Two Drivers of Sustainable Business Models}

In other words, we outline two different approaches to the sustainability problem. On the one hand, there are companies that take responsibility for their culpability in contributing to the problem and consequently take measures to reduce their negative impact on society and the environment. On the other hand, there are companies that see potential for solving the problem and consequently build business models that enable them to offer profitable products and services that address the footprint made by others. In addition, of course, there are companies that apply both approaches at the same time. This distinction between sustainability as responsibility and as opportunity can be illustrated as follows (Fig. 3.1).

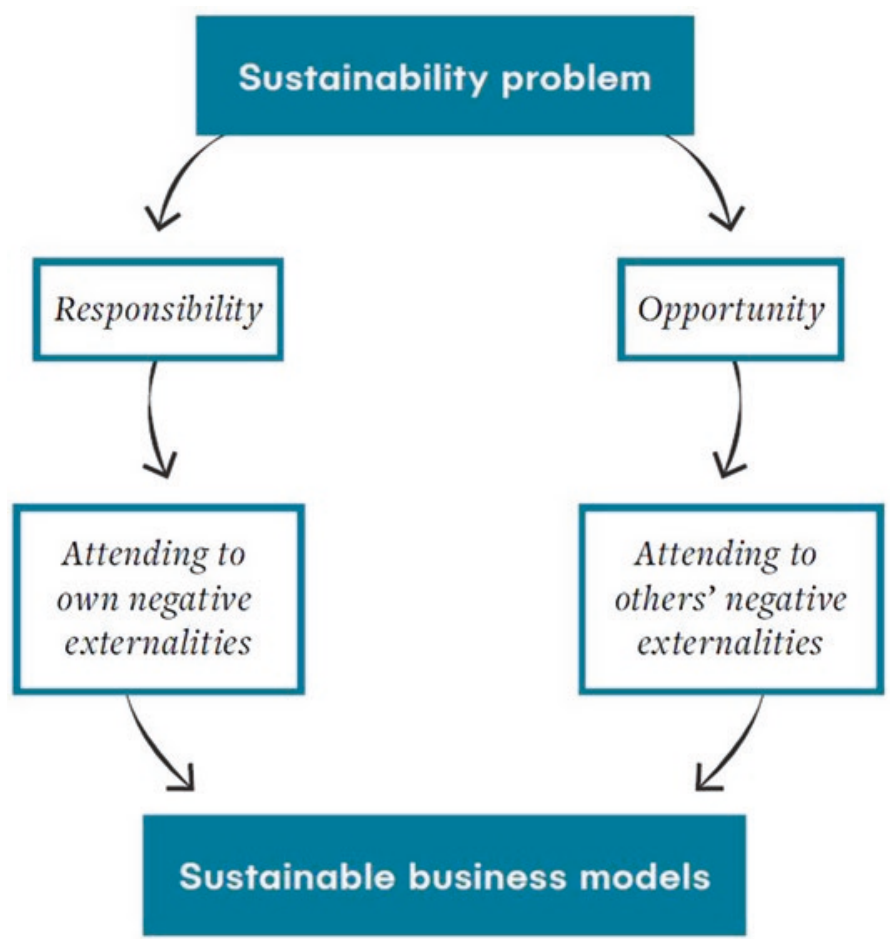

Fig. 3.1 Sustainability as responsibility and as opportunity (Jørgensen and Pedersen 2017) 
We use the term sustainability problem to denote the sum of challenges we face with regard to both society and the environment. The part of these problems arising from companies' operations are due to what we call negative externalities (Cornes and Sandler 1996). This refers to the negative effects of a company's activities on society and the environment, and it thus reflects an impact that would not have been there if the company did not exist. Depending on how the company sees its relationship to any given sustainability problem, it may experience a responsibility for the problem (e.g., Carroll 1999) or it may see an opportunity in resolving it (e.g., Jenkins 2009; Grayson and Hodges 2017). The former typically involves dealing with one's own negative externalities, whereas the latter typically involves helping to cope with the negative externalities of others. When we are talking about sustainable business models, such characteristics of the company are an integral part of the way it operates.

For some sustainability problems, it is common to think that individual companies are responsible (e.g., Freeman 2010). Seemingly, this was the experience of Ray Anderson when he initiated the turnaround at Interface. Similarly, such thinking might underlie Dell's desire to reduce the footprint of its operations by switching from oil-based to carbonnegative plastic. Thus, the company can tell its customers and other stakeholders that it is greening its operations. Other problems are clearly caused by others than the company itself, and there is little reason to argue that the company is responsible for such problems. For instance, Newlight is not responsible for the $\mathrm{CO}_{2}$ emissions of others. However, the company still sees a significant business opportunity in those problems, and consequently develops a business model by which it can contribute to solving the sustainability problem while making money thereof.

There are more and more examples that businesses find innovative solutions to solve sustainability problems profitably (Nidumolu et al. 2009; Porter and Kramer 2011). Companies are uniquely fitted to do this because they are basically problem solvers - they are designed to identify business opportunities in the problems faced by existing or potential customers and to find profitable ways to solve them. 


\section{Toward Sustainable Business Models}

When Mark Herrema and Kenton Kimmel founded Newlight in 2003, they were two young men who experimented with technology in their garage. The idea emerged from what was barely a start-up company. When Ray Anderson had his ecological epiphany, however, he had already been the CEO of the market-leading company Interface for 21 years, and he transformed the business model of the company completely. Such innovations are possible in small companies as well as large, in goodsproducing companies as well as in the service sector, in Norway as well as in California, and in modern knowledge-intensive companies as well as in organizations that are more traditional.

We will now take you on a journey from supermarkets in Paris to football pitches in Rio de Janeiro; from financial institutions in Bergen, Norway to technology companies in Silicon Valley; from clothing manufacturers in Madrid to industrial parks in Denmark. In all of these places, there are companies that have taken appropriate steps to become more sustainable, and that have succeeded in maintaining or increasing profitability at the same time. These firms have come a long way toward succeeding in implementing sustainable business model innovations. Many other companies could do so too.

\subsection{Sustainable and Profitable}

Does a recycling company need a sustainable business model innovation? In 2011, the private equity firm Altor bought the largest recycling company in Norway, Norsk Gjenvinning (NG), for about 250 million USD. The new owners quickly realized that the company was in need of a major cleanup.

In 2014, the company publicly disclosed details of the dirty practices hidden in the company's operations and in the waste industry in general. This was not popular in the industry. NG argued that in 2013 alone, it spent close to 15 million USD on a "moral cleanup" of the company, which has 1500 employees, 40,000 customers and approximately 
400 million USD in annual revenue. NG handles about 25 percent of all waste in Norway and operates in Sweden, Denmark and Great Britain as well. Among the issues that Altor discovered when taking over NG in 2011 was that a lot of money was being made by illegal means of getting rid of waste. Moreover, parts of the recycling industry were characterized by corruption, partly because of a cash economy and lax controls. Hazardous waste was not being handled in compliance with relevant laws, waste was exported illegally and there was considerable collusion between players in the industry.

The management team of NG, with CEO Erik Osmundsen in the lead, set a goal to achieve what they refer to as "real sustainability". They started in their own ranks, with a new vision and new corporate values. At the same time, they worked to get the rest of the industry, as well as the government and customers to understand the urgency of the situation. About half of the managers of the company were replaced, one of its former managers was jailed for 13 months and whistleblowing systems were designed to unveil all problems. NG's efforts to move in the direction of real sustainability continues unabated, and even in this supposedly "green" industry, improvement has required major corporate restructuring (Serafeim and Gombos 2015). At the end of 2017, the company's movement in this direction gained further momentum when Altor's stake was purchased by the private equity firm Summa Equityled by Reynir Indahl, one of the partners who had previously acquired NG when working at Altor. At the time of the acquisition, Indahl stated that " $[t]$ he company is proof of the financial attractiveness of providing solutions that improve environmental sustainability." The firm further added its intention to make NG a leader in the transition to a circular economythus improving the footprint of its business model in new ways.

\section{More of Everything That is Good}

The story of NG is largely a story about externalities - the positive and negative side effects of corporate activities on society and the environment. We call this the sunny side and the shadowy side of companies, respectively (Jørgensen and Pedersen 2015; Eells and Walton 1969). 
Through their operations, companies shed light and cast shadow. Put simply, companies shed light when they solve problems that are caused by others, and they cast shadows when they cause problems for others through their operations. NG strives to minimize the shadowy side of their operations, which includes corruption, pollution and much more. Moreover, the company aims to shed light by helping other businesses to become more sustainable. This is really the essence of the company's business model - it deals with excess resources and waste and brings them back into productive purposes, and at the same time, the company advises other companies on how to reduce their footprints (Serafeim and Gombos 2015). Among other things, NG collaborates with Norsk Hydro and Nespresso to create systems for recycling aluminum containers used for Nespresso coffee machines. Aluminum containers represent a big shadow of Nespresso's products and Norsk Hydro uses large amounts of energy to produce new aluminum but only five percent of its energy usage to recycle aluminum. Working together, all three players have found a marketbased solution that improves the total footprint of the companies' operations.

All organizations cast shadows and all businesses can shed more light. This applies not only to oil companies or to industry giants. Even a charity like the Red Cross has negative externalities, while it of course could have done even more to solve the world's problems. All organizations will necessarily to a greater or lesser extent cast shadows that would not have been there if they did not exist. Yet how extensive the shadows of the individual organization are will depend on the design of its business model-hence, it has an opportunity to design more sustainable business models. In the same way, all organizations also create some positive externalities that would not have been there if they did not exist, and we can therefore think in terms of "net impact" on society and the environment from any organization's operations.

NG want to contribute to what its managers call "real sustainability" - that is, not only implement measures to become more sustainable but also to attain the state of actually being in harmony with society and the environment. Therefore, the company aims to develop a business model that operates within planetary and societal boundaries. Interface has a stated goal of attaining a zero footprint by 2020, and Newlight has 
developed a production method that makes its plastic carbon negative. In different ways, then, these three actors expressed the same kind of objective: They do not want their companies cast unnecessary shadow-they even want to shed light, so that any positive consequences outweigh the negatives. They aim to achieve what is often called green growthincreased economic growth with reduced impact on society and the environment (Stoknes 2015). If so, they can provide a net positive contribution to our sustainability problems.

Figure 3.2 depicts the positive and negative externalities of a company-the total amount of light and shadow that follows from its operations (McDonough and Braungart 2010). On the vertical axis, we distinguish between what is 100 percent positive and what is 100 percent negative (both of which are of course theoretical—no company will end up in either of those extremes). The bars in the graph depict the company's sunny and shadowy sides. Companies with a large shadow side and a small sunny side would be placed in the far left of the diagram, while the far right would reflect the opposite. The dotted lines illustrate two desir-

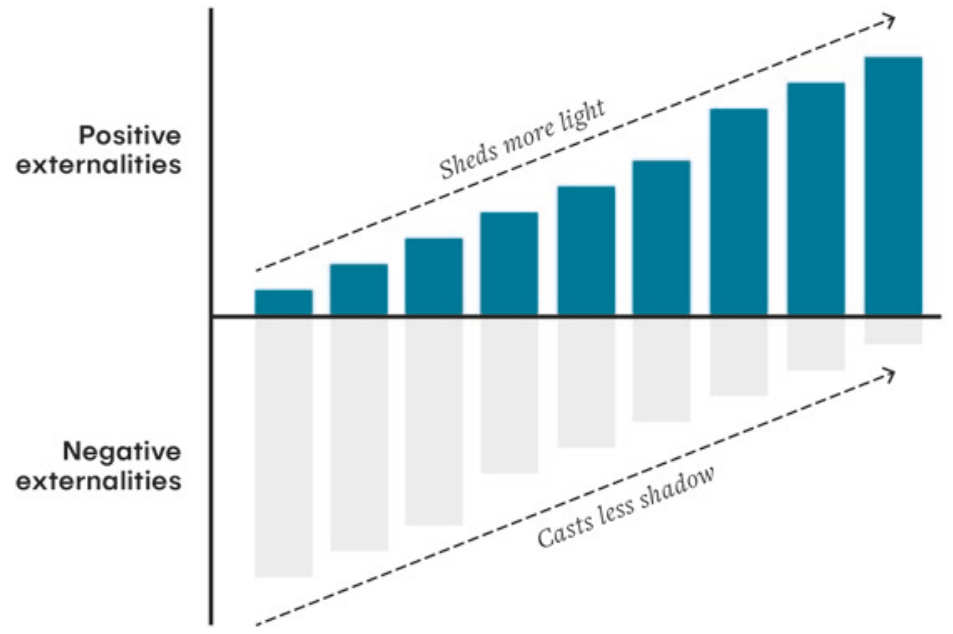

Fig. 3.2 The net effect of sustainability efforts (based on McDonough and Braungart 2010) 
able movements or trajectories, respectively, to shed more light and to cast less shadow. Both of these trajectories reflect contributions to more sustainable business, but it should be noted that reducing shadows is a linear movement toward zero footprint-it is about doing as little bad as possible. The other trajectory, however, is in some sense endless - there is no limit to how comprehensive a company's positive externalities might become, and in this sense, doing more good carries in it the potential for exponential positive impact.

An organization like the Red Cross would typically be placed at the right of the diagram, as one would see it as shedding much more light than shadow, from the societal and environmental points of view. Through ensuring children education, food and health care, it helps to reduce social inequalities and to ensure that children become environmentally aware. Meanwhile, of course, the Red Cross also has a shadowy side related to the negative effects of its operations, including travel, logistics and so on. Manufacturers of cluster bombs and gambling companies, however, would typically represent the far left in the diagram. This is because of their substantial shadows stemming from their core offerings, despite the fact that they obviously create jobs, pay taxes and that their operations have other positive effects.

What, then, is most important? Is it primarily desirable that companies shed light and thus contribute to positive consequences for society and the environment? Or is it more important that they "clean up their own nests" by taking steps to cast less shadow? The answer to this question perhaps depends on both the objectives of the company and the urgency of the sustainability issue in question. Any company that operates in an unsustainable manner is in a sense sawing of the branch on which it is sitting. The question is whether it is sufficient to saw more slowly or whether it needs to stop sawing altogether, that is, instead finding new and more sustainable ways of operating. Shortterm profitability can in many cases be achieved without thinking about light and shadow at all, but as we will see, the long-term profitability of companies is closely tied to their social and environmental performance. 


\subsection{The Next Step: Aligning Financial, Social and Environmental Bottom Lines}

In 2011, the sports equipment manufacturer PUMA, under the leadership of CEO Jochen Zeitz, published the company's first sustainability report. In this report, PUMA disclosed that the cost of its negative impact on the environment was 145 million euros, while its profits in the same year were 202 million euros.

If the company should have paid the cost of these negative externalities, its profits would thus have been reduced by 72 percent. In reality, PUMA's profits were largely borrowed from the resources of future generations. When presenting the sustainability report, Zeitz stated that we are overexploiting the resources and services that the environment provides and added, "The world has changed, and sustainable business cannot be expected or achieved without radical changes in our economic models. It's as simple as that."

When PUMA published its report, it also implemented a number of measures to reduce its shadow. However, the environmental data shows that PUMA is still in "debt" to Earth, although it is trying to become more sustainable. With few exceptions - such as $\mathrm{CO}_{2}$ emissions within the EU-a price has still not been put on the use of resources such as clean air, fresh water and topsoil. This means that the environmental costs PUMA refers to are not actual costs for companies-they do not have to be paid. In contrast, the consumption of these resources is a very real cost to the Earth, not at least for those who will live here after us (cf. Zeitz 2011).

What, then, is sustainable business? Simply put, it is about creating a harmonious and sustainable interaction between economy, society and the environment in which economic activity strengthens the social and environmental systems they exist within, rather than breaking them down (Lozano 2008; O’Higgins and Zsolnai 2017). Our perspective is a business-economic one, which implies that we look at the world from the point of view of companies. We are particularly concerned with the characteristics of companies that aim to attain both financial and non-financial objectives, both in the short and long term. However, as the example 
of PUMA illustrates, companies can shoot themselves in the foot if they do not take into account the social and environmental dimensions of their performance. Companies are directly dependent on society and the environment in the sense that their operations rely on both the human and natural resources extracted from these sources. Companies are also indirectly dependent on how their activities affect society and the environment since customers, employees, investors and other stakeholders can be more or less willing to support the company, depending on how they perceive its footprint.

\section{A Sustainable Interplay}

A sustainable future depends on a more harmonious interplay between business, society and the environment. Today, we are experiencing a comprehensive sustainability problem, partly because of the activities of business generating large negative externalities for society and the environment, while the positive externalities thereof are not extensive enough to compensate for companies' shadows. This is based on a simple, but important, premise for understanding how the economy, society and environment are interrelated, as illustrated in Fig. 3.3.

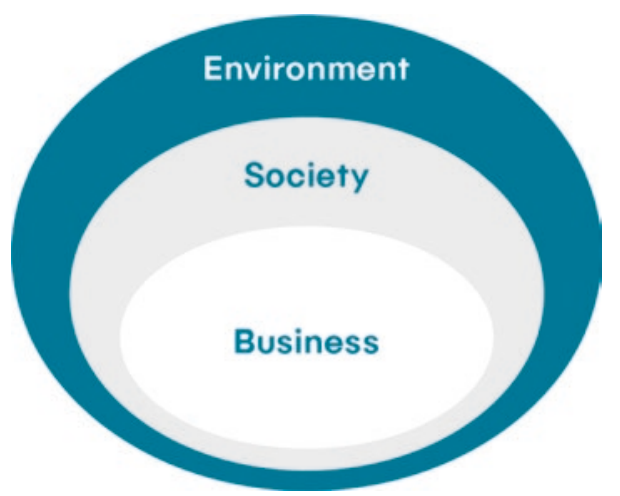

Fig. 3.3 A sustainable interaction between economy, society and environment 
The economic system exists within societal boundaries (e.g., Thompson and Macmillan 2010; Dyllick and Hockerts 2002). Companies supply resources of great value to society, such as salaries and important goods and services, and they also make use of societal resources, such as labor, and infrastructure, such as education, roads and so on. When we say that companies shed light and cast shadow on society, the sunny side relates to such issues as paying taxes, creating jobs and delivering products and services, while the shadowy side, for instance, relates to exploitation of workers, corruption, tax evasion, food products that lead to obesity and so on.

There is as such an intimate interplay between business and society, and over time, companies depend on a sustainable society in which there is trust, educational institutions that can provide workers with needed skills and well-functioning democratic systems as well as political and legal institutions that make business operations possible. When these assumptions fail, it harms companies that depend on these conditions (cf. Carroll and Shabana 2010).

Moreover, both business and society exist within environmental boundaries (Ingebrigtsen and Jakobsen 2007). This does not only relate to the physical environment on land. The environment extends deep into the oceans and far into space (Rockström et al. 2009). As shown in Fig. 3.3, society and the environment are both embedded in the ecological system. As described above, business and society are interdependent, and both of these two systems are reliant on nature. Earth can exist just fine without humans (cf. Holmes 2006), but humans are completely dependent on a viable ecological system. Of course, business activity also depends on inputs from nature, and it leaves behind a significant footprint on the environment, as PUMA's sustainability report aims to highlight.

When we talk about sustainability problems, we refer to a discord between these three systems, which cannot be sustainable over time. The challenge thus consists in finding business models that are in harmony with the three systems, so that they remain profitable while being more sustainable. Thankfully, we see that more and more companies are achieving this. It should, however, be noted that in the pursuit of more sustainable business, many companies will not survive. Perhaps many companies 
are simply not fit for the future. Perhaps there are products, serviceseven entire industries that we will get rid of in a more sustainable future. Another related, and important, point is that there are probably also limits to the problems that can be solved on the part of companies themselves. Regulations are clearly needed and perhaps other means of facilitating greener lifestyles, consumption patterns and solutions will also be necessary. The point of departure of this book is to investigate the solutions that can be offered by companies. And while they may lead to considerable business opportunities, attaining them will not be a simple feat.

\section{Sustainability Can Pay-But It is No Walk in the Park}

It is of course still possible to make money while completely ignoring any impact on society and the environment, and this will probably be the case for the foreseeable future (e.g., Hong and Kacperczyk 2009; Salaber 2007). Companies that are willing to compromise on social and environmental standards, for example, by producing goods in countries with no restrictions on either pollution or worker rights, will at least reap shortterm benefits thereof. It is entirely possible for companies to be irresponsible without going bankrupt. However, a number of developments-for example, related to sustainability reporting, regulation, changing customer preferences and increased attention from investors about environmental risks - suggest that it is becoming increasingly difficult to hide and to get away with irresponsible practices (see, e.g., Fernandez-Feijoo et al. 2014; Mol 2015; Unruh et al. 2016). Consequently, the best path to profitability is perhaps no longer leniency when it comes to social and environmental impact.

Recent research in fact suggests that companies that succeed in integrating sustainability into their overall strategies and business models are more profitable in the long term. This is the key finding in a study conducted by a group of researchers led by Robert G. Eccles at Harvard Business School (Eccles et al. 2015). They studied the effect of sustainability efforts on companies' financial performance and compared 180 US companies over a 20 -year period. They divided the firms into two 
groups: the so-called high and low sustainability companies, respectively. The companies are matched so that they are comparable in important characteristics that could explain differences in performance, so that any remaining differences in profitability can most likely be attributed to differences in the companies' approach to sustainability.

The conclusion of the study is that high sustainability firms over time outperform low sustainability firms, both when measured with stock market data and accounting data. The difference is greater for companies that are relatively more exposed to end consumers Business to customer (B2C) than for those who mostly sell to other companies Business to business (B2B). The difference is also greater for companies that compete on brand and reputation, and for companies that are more dependent on using large amounts of natural resources.

What, then, characterizes the sustainable companies? In these companies, the board of directors are more often responsible for corporate sustainability strategy and results, and they are more likely to have implemented financial incentives for senior executives that are linked to sustainability performance. Moreover, these companies have more comprehensive procedures and systems for stakeholder engagement, they have longer-term horizons, they are generally more open and transparent, and their control systems and reporting include both financial and nonfinancial measures. A number of these characteristics are also emphasized in other studies wherein companies self-report the characteristics of their sustainability efforts and the financial performance implications thereof.

We should note that although this study includes companies from a variety of industries, the sample is limited to US companies. It is in other words unclear if one would find similar results in markets in other parts of the world, although recent studies suggest that some of the same relationships exist, for example, in Scandinavian companies (Eccles et al. 2016; Gulbrandsen et al. 2015). Nevertheless, the trends we have described above suggest that the competitive advantages related to being sustainable will be stronger in the years to come. They are not easy to achieve, however, and although it is possible to align sustainability and profitability, it requires extensive changes in companies and their business models because the problems that need to be solved are comprehensive. 


\section{Our Collective Luxury Trap}

Every year, the Global Footprint Network (GFN) announces Earth Overshoot Day (see, e.g., Global Footprint Network 2011). It is the day of the year when we have used all the resources we have available that year if we were to manage our resources sustainably. In 2017, the day fell on 2 August — six days earlier than in 2016, when it was 8 August. Hence, we are moving in the wrong direction with quite some speed. We use a full year's worth of the earth's resources during the first eight months of the year, and for the remainder of the year, we borrow all the resources we consume from future generations. GFN has calculated that we need 1.6 planets to support our current consumption, while we of course only have access to one. By comparison, in 1960, we only needed three-quarters of our planet to support our consumption. Currently, the Earth's population is annually using more than 50 percent of its resources and producing more waste, including $\mathrm{CO}_{2}$, than the planet can handle.

One example is that every year, we emit twice as much $\mathrm{CO}_{2}$ that the forests and the sea manage to capture and turn into oxygen. With regard to greenhouse gas emissions alone, we need the equivalent of two planets. There are of course huge differences between countries: while it takes just less than four "Italies" to meet Italy's needs, we need more than 12 "Saudi Arabias" to support Saudi Arabia. Earth Overshoot Day is also referred to as Earth Debt Day, and our collective overconsumption can be seen as an ecological luxury trap, in which we borrow increasingly from the earth. Moreover, we transfer ecological debt to future generations, who will therefore have fewer resources to live from and will have to deal with a more unstable climate. They will thus incur great costs-both financial and non-financial-in order to deal with the situation that our current lifestyle imposes on them.

Such a debt-ridden development is clearly not sustainable since sustainable development is defined as development that meets present needs without compromising the ability of future generations to satisfy their needs. The term sustainable development was popularized through the UN report, Our Common Future, which was published by the World Commission on Environment and Development in 1987 (also known as 
the Brundtland Commission after its leader Gro Harlem Brundtland). Sustainable development is an overarching political understanding of the concept. Sustainability essentially refers to the survival of an ecological system, like a forest or an ocean. More recently, the concept has been used to refer to the broader survivability of both business and society (see also Dixon and Fallon 1989).

It is obvious that we are challenging the earth's carrying capacity. But how much can it endure? What kind of action space do we have? And how is the threat changing from year to year? The Stockholm Resilience Center (SRC) has developed a framework that covers nine planetary boundaries that are under pressure (e.g., Rockström et al. 2009). Each year, the center publishes reports in which they attempt to measure the progress in these nine areas. The nine areas together capture the planet's carrying capacity:

- Stratospheric ozone depletion

- Loss of biosphere integrity

- Chemical pollution and the release of novel entities

- Climate change

- Ocean acidification

- Freshwater consumption and the global hydrological cycle

- Land system change

- Nitrogen and phosphorus flows to the biosphere and oceans

- Atmospheric aerosol loading

According to the SRC, several of these areas are already under considerable pressure. The degree of pressure on each area varies, but the center also points out that due to unsafe methods of measurement, we do not yet have sufficient knowledge of the magnitude of the negative impact for many of these areas (cf. Steffen et al. 2015).

\section{Societal Boundaries}

In the same way that the planet has limits to what it can withstand, the societal fabric can also be stretched too far. However, we can obviously 
not see society and the environment as completely disconnected from each other (cf. Margolis and Walsh 2003; Smith et al. 2013). For example, we know that the environmental consequences of climate change are disproportionately borne by the poorest people in the world (see, e.g., Duraiappah 1998; Intergovernmental Panel on Climate Change 2014). Another example is the relationship between slave labor and greenhouse gas emissions. Recent research shows that the economic activity performed by slaves has a disproportionately high carbon footprint. Calculations conducted by the researcher Kevin Bales suggests that if slavery were a country, it would have had Canada's population and Angola's gross domestic product, but it would have been the third largest emitter of $\mathrm{CO}_{2}$ globally, surpassed only by China and the United States (Bales 2016). These examples show that there is a correlation between social and environmental problems and that they may therefore be mutually self-reinforcing. The upside of this is that one may in fact solve environmental problems by solving social problems and vice versa.

The social dimension of sustainability includes a variety of characteristics of the endurance of communities, which are not necessarily as easy to capture and measure as are the abovementioned environmental attributes (cf. Hutchins and Sutherland 2008). For instance, the UN Sustainable Development Goals (SDGs), which were published in 2015, include social phenomena such as poverty, health, gender equality, diversity, social justice and social inclusion. We know that poverty is giganticalmost half the world's population lives on less than 2.5 dollars a day, while economic inequality is increasing (cf. Banerjee and Duflo 2011; Atkinson 2015).

The social footprint of business affects all of these outcomes. When economic entities are corrupt, social justice is undermined and corruption maintained, and the differences between rich and poor may be worsened (Søreide 2016). When companies develop unhealthy or harmful products, this has consequences for both human health and quality of life (e.g., Collins and Fairchild 2007). And when companies enter markets with weak background institutions and carry out exploitative business practices in order to get cheap labor working under hazardous or highrisk conditions, several social values are under pressure (e.g., Simas et al. 2014). 
The business models of the future must be adapted to this resource situation. Companies rely on employees wanting to work for them. They also depend on societal legitimacy in order to maintain operations without being subject to activism, stricter regulations and negative reputational effects. And they rely on the social environment within which they operate being sufficiently safe and predictable so that they get the human and social resources they need.

The social boundaries are perhaps less tangible than are the planetary boundaries. We can identify when we are running out of precious metals and clean water, and we can observe the rising sea levels. We note rising average temperatures and the effects thereof. However, how do we know when the social fabric is about to break? Perhaps, then, is this challenge even more difficult to manage for companies than are the environmental ones, and in many instances such social issues will also be significantly more local in nature. Therefore, there might be reason to believe that companies are more likely to address problems related to environmental sustainability than those relating to social sustainability. That does not mean, however, that the latter category is not as important.

\section{Next Stop: RESTART}

PUMA realized that it really owed three-quarters of its profits to the planet because it was extracting more resources than it provided and because it polluted the planet and the atmosphere. In recent years, PUMA and many other companies have taken steps to contribute to more sustainable development. They are becoming "more sustainable" and over time, they will perhaps become "truly sustainable", which is the stated objective of Norsk Gjenvinning. Given the overall sustainability problems we have outlined above, however, it is easy to become both pessimistic and paralyzed. The warning lights are flashing in the measurements of the Stockholm Resilience Center. Even for the indicators where we are currently within the limits of the Earth's carrying capacity, such as the use of fresh water, the analysis shows that these resources are also under pressure. And there are problems seemingly not addressed by any companies because they do not perceive them as being important for their business performance.

The response from the global community is strikingly passive in the face of such dramatic developments. Moreover, while there are plenty of 
examples of companies that make large and small steps to become more sustainable-or at least appear to be-there are still relatively few of the kinds of business models of which we have sketched the contours above. The treasure chest of business models that make the world greener rather than browner therefore needs replenishing. We need more truly sustainable business models that can give us a RESTART.

\section{References}

Anderson, R. (2002). Mid-course correction: Toward a sustainable enterprise. Journal of Business Administration and Policy Analysis, 30, 415.

Atkinson, A. B. (2015). Inequality. Cambridge, MA: Harvard University Press. Bales, K. (2016). Blood and earth: Modern slavery, ecocide, and the secret to saving the world. Spiegel \& Grau.

Banerjee, A. V., \& Duflo, E. (2011). Poor economics: A radical rethinking of the way to fight global poverty. New York, NY: Public Affairs.

Boons, F., \& Lüdeke-Freund, F. (2013). Business models for sustainable innovation: State-of-the-art and steps towards a research agenda. Journal of Cleaner Production, 45, 9-19.

Botsman, R., \& Rogers, R. (2010). What's mine is yours. The rise of collaborative consumption. New York, NY: HarperCollins.

Carroll, A. B. (1999). Corporate social responsibility: Evolution of a definitional construct. Business \& Society, 38(3), 268-295.

Carroll, A. B., \& Shabana, K. M. (2010). The business case for corporate social responsibility: A review of concepts, research and practice. International Journal of Management Reviews, 12(1), 85-105.

Collins, A., \& Fairchild, R. (2007). Sustainable food consumption at a subnational level: An ecological footprint, nutritional and economic analysis. Journal of Environmental Policy \& Planning, 9(1), 5-30.

Cornes, R., \& Sandler, T. (1996). The theory of externalities, public goods, and club goods. Cambridge: Cambridge University Press.

Dixon, J. A., \& Fallon, L. A. (1989). The concept of sustainability: Origins, extensions, and usefulness for policy. Society \& Natural Resources, 2(1), 73-84.

Duraiappah, A. K. (1998). Poverty and environmental degradation: A review and analysis of the nexus. World Development, 26(12), 2169-2179.

Dyllick, T., \& Hockerts, K. (2002). Beyond the business case for corporate sustainability. Business Strategy and the Environment, 11(2), 130-141. 
Eccles, R. G., Feiner, A., \& Verheyden, T. (2016). Sustainability and financial performance of Scandinavian companies. Unpublished manuscript, Harvard Business School.

Eccles, R. G., Ioannou, I., \& Serafeim, G. (2015). The impact of corporate sustainability on organizational processes and performance. Management Science, 60(11), 2835-2857.

Eells, R. S. F., \& Walton, C. C. (1969). Conceptual foundations of business. Homewood, IL: R.D. Irwin.

Evans, A. (2011). Resource scarcity, climate change and the risk of violent conflict. Washington, DC: The World Bank.

Fernandez-Feijoo, B., Romero, S., \& Ruiz, S. (2014). Effect of stakeholders' pressure on transparency of sustainability reports within the GRI framework. Journal of Business Ethics, 122(1), 53-63.

Freeman, R. E. (2010). Strategic management: A stakeholder approach. Cambridge: Cambridge University Press.

Global Footprint Network. (2011). What happens when infinite-growth economy runs into a finite planet. Global Footprint Network 2011 Annual Report. Oakland, CA: Global Footprint Network.

Grayson, D., \& Hodges, A. (2017). Corporate social opportunity! Seven steps to make corporate social responsibility work for your business. Sheffield, UK: Greenleaf.

Gulbrandsen, E. A., Jørgensen, S., Kaarbøe, K., \& Pedersen, L. J. T. (2015). Developing management control systems for sustainable business models. Beta: Scandinavian Journal of Business Research, 29(1), 10-25.

Hawken, P. (1993). The ecology of commerce: How business can save the planet. London: Weidenfeld \& Nicolson.

Holmes, B. (2006). Earth without humans. New Scientist, 192(2573), 36-41.

Hong, H., \& Kacperczyk, M. (2009). The price of sin: The effects of social norms on markets. Journal of Financial Economics, 93(1), 15-36.

Hutchins, M. J., \& Sutherland, J. W. (2008). An exploration of measures of social sustainability and their application to supply chain decisions. Journal of Cleaner Production, 16(15), 1688-1698.

Ingebrigtsen, S., \& Jakobsen, O. D. (2007). Circulation economics: Theory and practice (Vol. 3). Oxford: Peter Lang.

Intergovernmental Panel on Climate Change. (2014). Climate change 2014 Impacts, adaptation and vulnerability: Regional aspects. Cambridge: Cambridge University Press.

Jenkins, H. (2009). A 'business opportunity' model of corporate social responsibility for small-and medium-sized enterprises. Business Ethics: A European Review, 18(1), 21-36. 
Jørgensen, S., \& Pedersen, L. J. T. (2015). Responsible and profitable: Strategies for sustainable business models. Oslo: Cappelen Damm Akademisk.

Jørgensen, S., \& Pedersen, L. J. T. (2017). Designing sustainable business models. In T. W. Andreassen, S. Clatworthy, M. Lüders, \& T. Hillestad (Eds.), Innovating for trust. Cheltenham, UK: Edward Elgar Publishing.

Khan, M., Serafeim, G., \& Yoon, A. (2016). Corporate sustainability: First evidence on materiality. Accounting Review, 91(6), 1697-1724.

Kiron, D., Kruschwitz, N., Haanaes, K., \& von Streng Velken, I. (2012). Sustainability nears a tipping point. MIT Sloan Management Review, 53(2), 69-74.

Krautkraemer, J. A. (1998). Nonrenewable resource scarcity. Journal of Economic Literature, 36(4), 2065-2107.

Lozano, R. (2008). Envisioning sustainability three-dimensionally. Journal of Cleaner Production, 16(17), 1838-1846.

Margolis, J. D., \& Walsh, J. P. (2003). Misery loves companies: Rethinking social initiatives by business. Administrative Science Quarterly, 48(2), 268-305.

McDonough, W., \& Braungart, M. (2010). Cradle to cradle: Remaking the way we make things. London: Macmillan.

Miller, K. D. (1992). A framework for integrated risk management in international business. Journal of International Business Studies, 23(2), 311-331.

Mol, A. P. (2015). Transparency and value chain sustainability. Journal of Cleaner Production, 107, 154-161.

Nidumolu, R., Prahalad, C. K., \& Rangaswami, M. R. (2009). Why sustainability is now the key driver of innovation. Harvard Business Review, 87(9), 56-64.

O’Higgins, E., \& Zsolnai, L. (Eds.). (2017). Progressive business models: Creating sustainable and pro-social enterprise. Springer.

Pachauri, R. K., \& Meyer, L. (red.) (2014). Climate change 2014: Synthesis report. Geneva, Switzerland: IPCC.

Rockström, J., Steffen, W., Noone, K., Persson, Å., Chapin, F. S., Lambin, E. F., \& Nykvist, B. (2009). A safe operating space for humanity. Nature, 461(7263), 472-475.

Salaber, J. M. (2007). The determinants of sin stock returns: Evidence on the European market. Working paper, Université Paris-Dauphine.

Sen, S., Du, S., \& Bhattacharya, C. B. (2016). Corporate social responsibility: A consumer psychology perspective. Current Opinion in Psychology, 10, 70-75.

Serafeim, G., \& Gombos, S. (2015). Turnaround at Norsk Gjenvinning. Harvard Business School Case, 1.

Simas, M. S., Golsteijn, L., Huijbregts, M. A., Wood, R., \& Hertwich, E. G. (2014). The "Bad Labor" footprint: Quantifying the social impacts of globalization. Sustainability, 6(11), 7514-7540. 
Skarmeas, D., \& Leonidou, C. N. (2013). When consumers doubt, watch out! The role of CSR skepticism. Journal of Business Research, 66(10), 1831-1838. Smith, W. K., Gonin, M., \& Besharov, M. L. (2013). Managing social-business tensions: A review and research agenda for social enterprise. Business Ethics Quarterly, 23(3), 407-442.

Søreide, T. (2016). Corruption and criminal justice: Bridging economic and legal perspectives. Edward Elgar Publishing.

Steffen, W., Richardson, K., Rockström, J., Cornell, S. E., Fetzer, I., Bennett, E. M., \& Folke, C. (2015). Planetary boundaries: Guiding human development on a changing planet. Science, 347(6223), 1259855.

Stoknes, P. E. (2015). What we think about when we try not to think about global warming: Toward a new psychology of climate action. Chelsea Green Publishing. Thompson, J. D., \& MacMillan, I. C. (2010). Business models: Creating new markets and societal wealth. Long Range Planning, 43(2), 291-307.

Unruh, G., Kiron, D., Kruschwitz, N., Reeves, M., Rubel, H., \& Zum Felde, A. M. (2016). Investing for a sustainable future: Investors care more about sustainability than many executives believe. MIT Sloan Management Review, 57(4), 3-25.

Wells, P. E. (2013). Business models for sustainability. Cheltenham, UK: Edward Elgar Publishing.

Zeitz, J. (2011). Puma completes first environmental profit and loss account. The Guardian, November 16.

Open Access This chapter is licensed under the terms of the Creative Commons Attribution-NonCommercial-NoDerivatives 4.0 International License (http:// creativecommons.org/licenses/by-nc-nd/4.0/), which permits any noncommercial use, sharing, distribution and reproduction in any medium or format, as long as you give appropriate credit to the original author(s) and the source, provide a link to the Creative Commons license and indicate if you modified the licensed material. You do not have permission under this license to share adapted material derived from this book or parts of it.

The images or other third party material in this chapter are included in the chapter's Creative Commons license, unless indicated otherwise in a credit line to the material. If material is not included in the chapter's Creative Commons license and your intended use is not permitted by statutory regulation or exceeds the permitted use, you will need to obtain permission directly from the copyright holder.

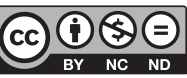

